2012

\title{
Use of Comparative Law in Determining the Customary International Law of Human Rights
}

Kenneth S. Gallant

University of Arkansas at Little Rock William H. Bowen School of Law, ksgallant@ualr.edu

Follow this and additional works at: http://lawrepository.ualr.edu/faculty_scholarship

Part of the Human Rights Law Commons, and the International Law Commons

\section{Recommended Citation}

Kenneth S. Gallant, Use of Comparative Law in Determining the Customary International Law of Human Rights, 24 Fla. J. Int'l L. 429 (2012).

This Essay is brought to you for free and open access by Bowen Law Repository: Scholarship \& Archives. It has been accepted for inclusion in Faculty Scholarship by an authorized administrator of Bowen Law Repository: Scholarship \& Archives. For more information, please contact mmserfass@ualr.edu. 


\title{
ESSAY \\ USE OF COMPARATIVE LAW IN DETERMINING THE CUSTOMARY INTERNATIONAL LAW OF HUMAN RIGHTS
}

\author{
Kenneth S. Gallant ${ }^{*}$
}

Much of the discussion of the universalization of individual human rights turns on whether it is appropriate to impose specific values on all societies around the world. ${ }^{1}$ This often transforms the discussion into a political discourse, which is not a necessarily a bad thing. Whether rights ought to be universalized necessarily turns on political theory and the concrete situation of humanity.

This trend does have negative effects, however. Generalized discussion of the concept of human rights distracts from examination of universalization of specific principles or rules of human rights law. It also tends to cover up the difference between the description of practice concerning each of these rights on the one hand, and the moral force of the arguments for or against universalization on the other. ${ }^{2}$

There is also an unfortunate tendency to make exaggerated claims that certain non-treaty statements of human rights law, especially the Universal Declaration of Human Rights (UDHR), ${ }^{3}$ have fully passed into customary international law. This is true even on the U.N. website: "The international community as a whole, moved by the universal juridical conscience, conferred upon the Universal Declaration the dimension that it has today, recognized in the international case law,

* The author is a Professor at the University of Arkansas at Little Rock, William H. Bowen School of Law, Little Rock, Arkansas, USA. A prior version of this piece was informally presented at XVIII International Congress of Comparative Law, Session on Public Freedom and Human Rights (IV.C.): Are Human Rights Universal and Binding? Limits of Universalism, July 29, 2010, Washington DC. The paper was not part of any National Report, or Reporter's Summary, which constituted the formal presentations at, and proceedings of, the session. Material from the International Congress cited herein is on file with the author. This Essay was completed with the assistance of a grant from the University of Arkansas at Little Rock, William H. Bowen School of Law.

1. See generally, e.g., David Kennedy, The International Human Rights Movement: Part of the Problem? 15 HaRV. HUM. RTS. J. 101 (2002); Thomas Franck, Are Human Rights Universal?, FOREIGN AFF. (Jan.-Feb. 2001); Andrew Fagan Human Rights, Internet Encyclopedia of Philosophy , I 5, http://www.iep.utm.edu/hum-rts/\#H5 (last updated July 5, 2005).

2. U.N.G.A. Res. 217 (III) (10 Dec. 1948) (approved 48-0, with 8 abstentions).

3. E.g., John P. Humphries, Human Rights and the United Nations: A great ADVENTURE 73-77 (1984). Humphries, as one of the major figures in the creation of the UDHR, has more right than most to boast of this, and he does at least discuss opposing views. 
incorporated in the domain of customary international law, and gave expression to some general principles of law universally recognized." It also appears in popular digital culture on the Internet:

Many international lawyers, in addition, believe that the Declaration forms part of customary international law and is a powerful tool in applying diplomatic and moral pressure to governments that violate any of its articles. The 1968 United Nations International Conference on Human Rights advised that it "constitutes an obligation for the members of the international community" to all persons.

To similar effect was a nearly contemporaneous statement of a group of major non-governmental organizations. ${ }^{6}$ This pattern is not always limited to the use by members of the public of the UDHR as a source of human rights. It exists, for example, in the practice of the International Criminal Tribunal for the Former Yugoslavia (ICTY). As Theodore Meron has stated: "Its practice was . . . akin more to that applied in the human rights field than in other areas of international law. In both human rights and humanitarian law, emphasis on opinio juris helps to compensate for scarcity of supporting practice." $\mathrm{He}$ goes on to indicate dissatisfaction with this method, arguing that the ICTY might have looked further "to identify actual state practice." 8

Careful scholarly efforts will often say that "some" or "many" provisions of the UDHR have passed into customary international law. ${ }^{9}$ However, even these works often do not specify which of the rights set out in the UDHR have become customary international law, do not identify the specific content of each of these rights, or do not provide the documentation of state practice and opinio juris necessary to demonstrate the customary international law nature of these rights. ${ }^{10}$

4. Antônio Augusto Cançado Trindade, The Universal Declaration of Human Rights, Introduction, available at http://untreaty.un.org/ cod/avl/ha/udhr/udhr.html (U.N. Audio-Visual Library of International Law, last visited Sept. 2, 2011) (quoting Proclamation of Teheran, U.N. GAOR, 23d Sess., U.N. Doc. A/CONF. 32/41 (1968)).

5. Wikipedia, Universal Declaration of Human Rights, at http://en.wikipedia.org/wiki/ Universal_declaration_of_human_rights (as visited Sept. 2, 2011) (subject to anonymous change without notice).

6. Montreal Statement of the Assembly for Human Rights, March 22-27, 1968, reprinted in 9 J. INT'L COMM'N JURISTS 94 (1969).

7. Theodore Meron, War Crimes Law Comes of Age 264 (1998).

8. Id. at 265 .

9. See Hurst Hannum, The UDHR in National and International Law, 3 HEALTH \& HUM. RTS. 144, 148-49, 156 n.23 (1998) (collecting sources using both "some" and "many"); see also AMERICAN LAW INSTITUTE, RESTATEMENT (THIRD), FOREIGN RELATIONS LAW OF THE UNITED STATES, Part VII, Law of Human Rights, Introductory Note (1987).

10. See id. $\S 702$, cmt. a (listing some human rights as having passed into customary 
These patterns create an important problem in the traditional rhetoric of human rights and human rights law. Overstatement leads to a devaluing of the customary international law of human rights. Specifically, if broad statements are made concerning the customary status of certain human rights, without sufficient actual practice to back up the statements, the statements will be viewed with suspicion. ${ }^{11}$ Similar statements about other rights, for which there is practice, may also be viewed with unjustified suspicion. Indeed, this can lead to the view that international human rights law is not truly "law," at least outside the context of human rights treaty law.

The less evidence of both practice and opinio juris that is presented, the "softer" the resulting law appears. ${ }^{12}$ Yet, human rights law, which attempts to enforce internal standards on states, needs for this very reason to be as "hard" as it can be made. A session on Universalization of Human Rights at the recent XVIII International Congress of Comparative Law points in this different direction, with a fuller grounding in practice around the world. Participants discussed actual national practice and official opinion (opinio juris) with regard to international human rights, as defined through international, regional and national mechanisms.

They also presented national views with regard to the universality of these human rights (i.e., their universal normative force, if any). Critically, though at a comparative law conference, they addressed the perspective of international law in examining the universality of the rights contained in the Covenants of 1966 and other international and regional human rights instruments. ${ }^{13}$ Perhaps because of humans' need to categorize, both the Questionnaire and the National Reports have continued to treat all human rights together for purposes of universalization. The most general distinction that we see among human rights is the specific inclusion in the National Reports of Portugal, Russia, and some other countries of "positive" human rights (generally those included in the International Covenant on Economic, Social, and Cultural Rights) along with the "negative" rights included in the International Covenant on Civil and Political Rights (ICCPR); others focus only on ICCPR-type rights. ${ }^{14}$ However, as the National Reporter

international law, but then stating in the comment that this list is "not necessarily complete," and not providing in the documentary material evidence for the passage of the listed rights into customary international law); see generally Hannum, supra note 9.

11. MERON, supra note 7, at 263-65.

12. See id.

13. Rainer Arnold, General Reporter's Questionnaire, Are human rights universal and binding? (Les droits des l'homme, sont-ils universels et normatives?). Professor Arnold is preparing the formal reports for publication as a book by Springer Publishing. See cmt. O15.

14. See id. cmts. O16 \& O19. 
for Singapore stated in the discussion, some rights in each category may have been universalized, others may not have been. ${ }^{15}$ The analysis must proceed right-by-right if it is to provide an accurate description of normative practice.

Accurate description of the universalization (or not) of human rights requires the fusion of techniques of comparative law and public international law. International human rights law as a scientific discipline requires determining what rights have become universalized as part of customary international law, or perhaps as general principles of law, and what the specific content of the universalized versions of those rights are. These are matters of public international law. If we want to say that a right is universal, we must effectively show either that it is universally adopted by treaty, that it has become customary international law, or that it embodies a general principle of law present in the major legal systems of the world. ${ }^{16}$

Universal treaty law dealing with specific human rights is rare. (A few near-universal treaties are the four Geneva Conventions of 1949, and the Convention on the Rights of the Child. ${ }^{17}$ ) Determining universality or near-universality here is a matter of treaty interpretation. Yet, even international human rights treaty analysis may require comparative technique: treaties may "differ in character, in subjective scope, in range, and they function (and bind) differently as sources of law."18

Determination of rights defined by customary international law and general principles of law involves understanding what is the actual practice (including the internal law) of states (and international organizations operating within their areas of competence ${ }^{19}$ ). Showing

15. See id. cmt. O20.

16. Cf., e.g., Statute of the International Court of Justice, art. 38(1) (generally viewed as stating the sources of international law, although applying directly only to cases in the ICJ). Note that, at least in terms of general principles of criminal law and procedure, the system of international criminal courts and tribunals is becoming a new legal system, alongside civil law, common law, Islamic law and other national systems. For a demonstration of the use of general principles of law as a means of defining human rights, see Bruno Simma \& Philip Alston, The Sources of Human Rights Law: Custom, Jus Cogens, and General Principles, 12 AUsTL. Y.B. INT'L L. 82, 106 (1992), quoted and discussed in Richard B. Lillich, The Growing Importance of Customary International Human Rights Law, 25 GA. J. INT'L \& COMP. LAW 1 (1995/96).

17. Convention on the Rights of the Child, G.A. Res. 44/25, Annex, U.N. Doc. A/RES/44/25 (Nov. 20, 1989); Geneva Convention Relative to the Protection of Civilian Persons in Time of War, Oct. 21, 1950, 75 U.N.T.S. 287.

18. Id. at 1 (discussing, e.g., the differences in universalism when a treaty covers persons, for example, women or children or acts, for example, torture).

19. See Kenneth S. Gallant, International Criminal Courts and the Making of Public International Law: New Roles for International Organizations and Individuals, 43 J. MARSHALL L. REV. 603 (2010) (international organizations now provide instances of practice which are used in constituting and identifying customary international law). 
that something has become customary international law also requires learning the opinio juris of these entities with respect to their practice (i.e., that they believe their practice is consistent with or required by $\operatorname{law}^{20}$ ).

Human rights law (whether domestic or international) deals with the relationship of governments with their own nationals as well the nationals of other states. State practice with regard to international human rights necessarily includes internal national practice, such as domestic constitutional provisions and statutes affecting both nationals and non-nationals. ${ }^{21}$ This differs from the traditional view of public international law practice as dealing only with interactions among states.

To understand what is customary international human rights law or a general principle of law in the area of human rights, one must actually compare laws; one must consider what the law on a suggested human right is in a broad variety of states that includes states from different legal cultures of the world. These laws must be contrasted with each other to find the common elements that comprise a general principle of law, and to determine those elements on which no consensus exists. This task is pre-eminently that of comparative law. ${ }^{22}$ The Polish National Report points out that one may look at different rights differently, that rights may have different content in different countries and at different times, that rights may be enforced differently, and so on. ${ }^{23}$

This comparative law approach need not be limited to international human rights law. As one example, the International Court of Justice recently used national law as practice to determine customary international law of criminal immunity of high foreign officials. ${ }^{24}$ In the Arrest Warrant case, the ICJ "carefully examined state practice, including legislation and those few decisions of national higher courts" in determining that customary international law did not permit prosecution of a sitting foreign minister in the courts of another state for crimes against humanity, when the state of which he was foreign minister claimed immunity for him. ${ }^{25}$ One distinguished commentator after World War II went even further: "if a practice is generally

20. See, e.g., Malcolm N. Shaw, International Law 84, 84-89 (6th ed. 2008) (collecting major sources).

21. See Anthea Elizabeth Roberts, Traditional and Modern Approaches to Customary International Law: A Reconciliation, 95 AM. J. INT'L L. 757, 788 (2001).

22. See generally material prepared for Opening Plenary: The Role of Comparative Law in Courts and International Tribunals, at this Congress.

23. Id. at $1-2$.

24. Case Concerning the Arrest Warrant of 11 Apr. 2000 (Democratic Republic of Congo v. Belgium), Judgment, ๆ 58, [2002] I.C.J. 3, 24 (14 Feb. 2002).

25. Id. 
regarded by states in their conduct of internal affairs as representing a principle of justice, it is also enforceable as a rule of customary international law." ${ }^{26}$ As another example, Professor Mireille DelmasMarty has recently shown the need to use comparative law in the determination of the substance of international criminal law, and how it has been done in the International Criminal Tribunals for the Former Yugoslavia and Rwanda. ${ }^{27}$

I would like to demonstrate the fusion of international and comparative law using an example from human rights law that is rather straightforward: the prohibition against retroactive creation of criminal law to convict a person of an act which was non-criminal when done. ${ }^{28}$ This rule is often stated as the maxim nullum crimen sine lege ("nothing is a crime without a [pre-existing] law against it") or as the prohibition of ex post facto criminal law. ${ }^{29}$ It appears in the UDHR, the ICCPR, regional human rights instruments, international humanitarian law and other treaties, and the domestic law of the vast majority of states. ${ }^{30}$ The law implementing this prohibition, however, varies from nation to nation, and even to some extent from treaty to treaty. ${ }^{31}$

A general prohibition against retroactive crime creation appeared in one way or another in the law of nearly every country. It appears in the constitutions of over $80 \%$ of U.N. Member States. ${ }^{32}$ Of the remaining states, several have the prohibition in their penal codes and a few in their general human rights legislation or elsewhere in their statutory law. ${ }^{33}$ Finally, almost all of the rest had adopted the ICCPR and one of the general regional human rights treaties which require non-

26. George Brand, The Sources of International Criminal Law, 15 U.N. WAR CRIMES COMmission, LaW RePORTS OF Trials of WaR Criminals 5, 6-7 (published for the U.N. War Crimes Commission by H.M. Stationery Office, 1947-49) (authorship attributed in Forward by Lord Wright of Durley, id. at x), relying on The Hostages Case, as excerpted at 8 U.N. WAR Crimes Commission, LAW RePorts of Trials of WAR CRIMINals 34, 49-50, and citing to The Schoenfeld Case, 11 U.N. WAR CRIMES COMMISSION, LAW REPORTS OF Trials OF WaR CRIMINALS, supra, at 72-73.

27. Mireille Delmas-Marty, Comparative Criminal Law as a Necessary Tool for the Application of International Criminal Law, in THE OXFORD COMPANION TO INTERNATIONAL JusTICE 97 (Antonio Cassese ed., 2009).

28. See Kenneth S. Gallant, The Principle of Legality in International and COMPARATIVE CRIMINAL LAW (2009) (detailing thoroughly the existing non-retroactivity provisions and their patterns in different world legal systems). For purposes of simplicity in the current Essay, issues concerning non-retroactivity of increased punishments are omitted, as are a few exceptions in a few countries.

29. See generally id. at 11-14.

30. Universal Declaration of Human Rights, art. 11; International Covenant on Civil and Political Rights, art. 15; for other sources, see generally GALLANT, supra note 28.

31. GaLlanT, supra note 28.

32. Id. at 244 n. 48 (listing provisions).

33. Id. at $246-48$. 
retroactivity of crime creation. ${ }^{34}$ The only three generally recognized states which have no constitutional or statutory provisions, or general treaty obligations to observe non-retroactivity of crime creation have adopted treaties requiring that it be applied in specific situations indicating that they cannot be hostile to the rule in general. ${ }^{35}$ So the entire world, at some level, accepts this principle.

Without application of comparative law techniques, however, this inquiry would be incomplete. There are important variations in the statement and implementation of this right across states and within the international criminal justice system. ${ }^{36}$

For example, many countries follow the example in Article 8 of the French Declaration of the Rights of Man and the Citizen, applying a rule that no act can be criminal except pursuant to a previously enacted statute. $^{37}$ Indeed, for many, this is the appropriate principle of nonretroactivity, which ought to be enshrined in the law. Anything which derogates from it does not fully implement the principle of requiring a clear, previously announced statement of what is prohibited. ${ }^{38}$

Comparative law, however, teaches us that we must look at actual practice across legal cultures. When this is done, we see that many countries' constitutions follow something like the text of the Universal Declaration of Human Rights: "No one shall be held guilty of a penal offense on account of any act or omission which did not constitute a penal offense, under national or international law, at the time when it was committed." 39 This respects the common law tradition of nonstatutory criminal definitions because it does not require a statutory statement of what constitutes a penal offense, yet still requires that the act have been a crime at the time committed.

This has also become the legality rule for international criminal law in international criminal courts and tribunals; so long as charged acts of genocide, crimes against humanity or war crimes were crimes under international law when committed, they may be prosecuted under the later statutes of those tribunals. ${ }^{40}$ Note here that the international legal

34. Id. at $248-49$.

35. Id. at 250-51 (Brunei, Bhutan, and Vatican City are all parties to the Convention on the Rights of the Child, prohibiting retroactive crime creation as to children; the latter two are parties to Additional Protocol II (1977) to the Geneva Conventions (1949)).

36. See GallanT, supra note 28, at 251-61.

37. Declaration of the Rights of Man and of the Citizen, Aug. 26, 1789, art. 8 (Fr.).

38. See GaLlant, supra note 28 , at 25-26, 33-36 (discussing why legislation may be superior to making criminal rules through common law).

39. U.N.G.A. Res. 217 (III), supra note 2, art. 11(2).

40. See, e.g., Prosecutor v. Tadic, Case No. IT-94-1-I, Decision on Defence Motion for Interlocutory Appeal on Jurisdiction, ๆा 135-45 (Int'l Crim. Trib. for the Former Yugoslavia Oct. 2, 1995); Prosecutor v. Milutinovic, Case No. IT-99-37-AR72, Decision on Dragoljub Ojdanic's Motion Challenging Jurisdiction: Joint Criminal Enterprise, I 10 (Int'l Crim. Trib. for 
system is itself becoming a subject of the study of comparative law. In this case, the international criminal justice system is becoming another legal system of the world, which needs to be set for comparison alongside common law, civil law, Islamic law, and other types of national law systems.

Comparative law also has a great deal to say about human rights development over time. For example, Islamic comparativist Haidar Ala Hamoudi and others have pointed out that ta'azir crimes in traditional Islamic law were sometimes created retroactively. ${ }^{41}$ Without this work, it would not be possible to see the importance of the inclusion of nonretroactivity of crime creation in the recently-effective Revised Arab Charter of Human Rights, ${ }^{42}$ nor the importance of the fact that nearly all Islamic majority countries have now put general non-retroactivity provisions into their laws. ${ }^{43}$

Similarly, nations formerly or currently adopting the socialist legal system have in the past twenty years or so moved, nearly en masse, to accepting non-retroactivity of crimes. ${ }^{44}$ For nations representing two major legal systems (Islamic and socialist) to accept a new human rights limitation in their national laws is very significant when considering the universality of that limitation.

When worldwide practice is examined, one sees that all countries generally accept a rule like that of the UDHR, that an innocent act may not be criminalized retroactively. ${ }^{45}$ However, some countries, and the international criminal law system, do not fully accept the stronger definition of non-retroactivity from the French Declaration of the Rights of Man and of the Citizen.

Thus, the right to be free of punishment for retroactively-created crimes has only been universalized to the extent of the version stated in the UDHR. Without the inclusion of the comparative law perspective,

the Former Yugoslavia May 21, 2003); Prosecutor v. Akayesu, Case No. ICTR-96-4-T, Judgment, I 617 (Sept. 2, 1998) (applying relevant treaty law adopted into domestic law, and discussing customary international law); Prosecutor v. Norman, Case No. SCSL 04-14AR72(E), Decision on Preliminary Motion Based on Lack of Jurisdiction (May 31, 2004);see generally GALLANT, supra note 28 (discussing, e.g., U.N. Sec. Council, Report of the SecretaryGeneral Pursuant to Paragraph 2 of Security Council Resolution808 (1993), U.N. Doc. S/25704, I 34 (May 3, 1993). But cf. Rome Statute of the International Criminal Court, art. 11, U.N. Doc. A/CONF.183/9 (July 17, 1998) (prohibiting exercise of jurisdiction over crimes occurring before the creation of the ICC).

41. Haidar Ala Hamoudi, The Muezzin's Call and the Dow Jones Bell: On the Necessity of Realism in the Study of Islamic Law, 56 AM. J. COMP. L. 423 (2008).

42. League of Arab States, Arab Charter on Human Rights, art. 15 (Sept. 15, 1994)

43. GALLANT, supra note 28 , at 270-71.

44. Id.

45. Again, for purposes of simplicity, this Essay leaves out discussion of acts at the "edges" of criminal definitions, which might foreseeably be held to be within the definition of crime. 
however, it would be difficult to see the strength of the trend of universalization. The general human rights treaties are not quite universally accepted and large regions-especially Asia and Oceaniado not have regional human rights treaties. Therefore, a "pure" international treaty analysis would not reveal the extent of universalization without the examination of domestic constitutional and statutory law of the non-treaty states. Similarly, without the comparative law perspective, one might not understand the significance of the difference between the UDHR version of non-retroactivity and its stronger French-origin version. Certainly, without bringing comparative law into the picture, one could not determine which version has been universalized as a matter of customary international law or as general principles of law accepted by the legal systems of the world.

Non-retroactivity of crimes is a relatively straightforward instance of the universalization of a human right. Understanding it requires a straightforward comparative technique-examining different implementations of the right to discover its common core.

Not all uses of comparative technique to discover whether a human right has been universalized and to what extent universalization has happened will be so easy. One can imagine, for example, that the implementations of freedom of expression show much greater variation from country to country. Attitudes concerning exceptions and limitation on the right vary greatly. It is also the case that far more states which have ratified human rights conventions have political systems which more or less regularly violate any sensible definition of this right. Thus, in this case, it will be much more difficult to determine how much of the principle of free expression has become a rule of customary international law, or even what the general principles of law concerning free expression may be.

Another important issue concerning the universalization and particularization of human rights is being discussed at this Congress: torture and other forms of cruel, inhuman and degrading treatment. A special plenary session addressed the question "to what extent the cultural heritage of an individual may have bearing on analyzing whether acts constitute torture ... [and] to what extent space exists for cultural relativism in this context[?] ${ }^{, 46}$ Here we can see that other

46. Plenary, The Prohibition of Torture and Cultural Relativism, 30 July 2010, Agenda description, available at http:/www.wcl. american.edu/events/2010congress/agenda.en.cfm (last visited Sept. 4, 2011). The agenda description uses the definition of torture from Article 1 of the U.N. Convention against Torture and Other Cruel, Inhuman or Degrading Treatment or Punishment (ratified by 146 countries). However, it is generally agreed that torture is prohibited by customary international law as well (though the content of the customary international law definition is not universally agreed upon). Because this was a special session, no General Report has been posted on the Congress's website. The author hopes the work of this session will be 
comparative techniques might be used. One might, for example, find the universal principles embodied in the prohibition of torture, perhaps using the techniques above. Then, one would examine specific cultural contexts to determine whether a given practice would violate these principles in a specific culture or set of cultures. ${ }^{47}$ Here, comparative law might be used both in determining the universal content of the prohibition and in particularizing the acts prohibited in any given culture and legal system.

In sum, it is not enough simply to say that the essence of a right is universal, but that implementation of that right may vary among countries. The comparative law perspective allows us to sort through the various national implementations of a right to determine just what its universalized content is-what has become customary international law.

This analysis may demonstrate that key moral principles behind a given "human right" have not yet become universalized. Even worse, in the case of some rights which we would like to consider "universal," the analysis may show that no rule of customary international law has emerged, or even that no general principle of law exists. This would mean that, as a matter of actual international law, these human rights depend on treaty adoption, interpretation and application, and on future effort to change practice so that they become truly universal.

published in another form. Another session addressed Religion and the Secular State (Session 1.b). However, because there is not yet universal agreement on whether states should be secular, it will not be further discussed in this very brief Essay. An interim version of the Reports for that session is available at https:/www.wcl.american.edu/events/2010congress/reports/ General_Reports/I_B_Religion_and_the_Secular_State_-_Interim_Reports.pdf?rd=1 (last visited Aug. 2010).

47. For example, one will sometimes see in the South Asian press discussion of whether placing leather shoes on the heads of prisoners or those being investigated for crime constitutes torture or cruel, inhuman or degrading treatment. In the context of most South Asian cultures, this is a powerfully degrading act, which for many people would cause extreme mental and emotional suffering. In many other cultures, this act does not have a similar degrading force. 